\title{
IMPROVED EXPONENTIAL APPROACH METHOD DAN ZERO SUFFIX METHOD DALAM MENENTUKAN SOLUSI OPTIMAL PADA MASALAH TRANSPORTASI
}

\author{
Istiqomah $^{1 \S}$, Ni Ketut Tari Tastrawati ${ }^{2}$, Luh Putu Ida Harini ${ }^{3}$

\begin{abstract}
${ }^{1}$ Program Studi Matematika, Fakultas MIPA - Universitas Udayana [Email: Istiqomahh48@gmail.com] ${ }^{2}$ Program Studi Matematika, Fakultas MIPA - Universitas Udayana [Email: tastrawati@unud.ac.id] ${ }^{3}$ Program Studi Matematika, Fakultas MIPA - Universitas Udayana [Email: ballidah@unud.ac.id ]

${ }^{\S}$ Corresponding Author
\end{abstract}

\begin{abstract}
The problem of transportation is a problem of distributing goods from several sources to several destinations with the aim of minimizing shipping costs. Distribution activities in a company sometimes experience problems in transportation problems so that a model is needed to determine the optimal distribution using the transportation model. This study aims to determine the route of distribution of beras putri sejati $25 \mathrm{~kg}$ in UD Sinar Jaya Abadi so that optimal expenses can be obtained using improved exponential approach and zero suffix method. Based on the calculation results, both methods produce the same three distribution path. The first distribution channel is from Agen Monang Maning to Toko Mekar Sari and Subur Jaya. The second distribution line from the Agen Gatsu Barat to UD Mas Ayana and Toko Dharma. The third line from agen Gianyar to UD Sinar Wangi, Toko Sari Artha, UD Amertha, and Toko Ayu Mega with optimal distribution costs of Rp 1.575.815.00. The difference or efficiency of the total costs incurred in the distribution before and after optimization by UD Sinar Jaya Abadi Rp 499, 190.00 or $24 \%$.
\end{abstract}

Keywords : Distribution, Improved Exponential Approach, Zero Suffix, Transportations model

\section{PENDAhUluan}

Beras merupakan sumber makanan pokok masyarakat Indonesia. Menurut Badan Pusat Statistik tahun 2017 kebutuhan masyarakat Indonesia akan beras meningkat setiap tahunnya. Hal ini mengakibatkan banyak perusahaan pendistribusian beras bersaing untuk dapat memberikan kualitas produk beras yang baik dengan harapan mengeluarkan biaya distribusi minimum sedemikian hingga dapat memperoleh keuntungan maksimum. Harapan tersebut dapat dicapai apabila sebuah perusahaan mempertimbangkan beberapa faktor salah satunya persoalan transportasi.

Persoalan transportasi merupakan salah satu persoalan pemrograman linear dalam menentukan cara pendistribusian suatu barang dari sumber ke tujuan dengan mengalokasikan barang yang ada pada sumber sedemikian rupa hingga kebutuhan pada tujuannya terpenuhi (Kertiasih, 2012). Adapun beberapa aspek yang harus diperhatikan saat melakukan proses pendistribusian yaitu kualitas produk, biaya distribusi, dan rute yang akan ditempuh (Karundeng dkk., 2018). Namun tidak semua perusahaan dapat memperhatikan hal tersebut sehingga untuk mengatasi permasalahan tersebut dapat digunakan model transportasi.

Pada model transportasi terdapat beberapa metode tak langsung dan metode langsung. Metode langsung merupakan metode yang dapat memperoleh solusi optimal tanpa harus mencari solusi awal. Beberapa metode tersebut di antaranya yaitu metode zero neigbouring, zero suffix, metode exponential approach, metode asm dan sebagainya. Metode-metode tersebut telah menemukan solusi yang optimal dalam masalah transportasi yang seimbang. Akan tetapi pada masalah transportasi yang tidak seimbang belum tentu dapat menemukan solusi yang optimal (Septiana dkk., 2017)

Terdapat pengembangan dalam memperbaiki kelemahan tersebut salah satunya yaitu pada metode exponential approach. Pengalokasian jumlah barang pada metode tersebut bergantung pada angka nol yang 
muncul pada tabel transportasi. Pada kasus transportasi tidak seimbang akan terdapat penambahan variabel dummy dengan asumsi biaya distribusi sebesar nol yang berpengaruh terhadap hasil optimalnya. Sehingga dikembangkan menjadi metode improved exponential approach (Hidayat, 2016).

Sehubungan dengan penerapan metode transportasi, adapun menurut Hasan (2012) menggunakan metode zero suffix telah didapatkan biaya distribusi yang optimal dibandingkan dengan menggunakan metode VAM-MODI pada kasus transportasi tidak seimbang. Kemudian menurut Hidayat (2016) menggunakan metode improved exponential approach pada masalah transportasi tidak seimbang diperoleh biaya pendistribusian pada PT. Prima Jasa Logistik Bulog Cabang Jawa Tengah telah optimal dibandingkan dengan menggunakan metode exponential approach. Kemudian penelitian yang dilakukan Purwanti, dkk (2019) menggunakan metode zero suffix pada masalah transportasi tidak seimbang pada Perum Bulog Divre Kalbar Pontianak juga telah didapatkan biaya distribusi yang optimal.

Berdasarkan penelitian terdahulu, penelitian ini bertujuan untuk mengetahui perbandingan metode improved exponential approach dan zero suffix dalam menentukan solusi optimal pada masalah transportasi yang dialami oleh UD Sinar Jaya Abadi. Perusahaan ini bergerak dalam bidang pendistribusian beras. Namun perusahaan ini belum menggunakan metode khusus untuk mendistribusikan produk berasnya. Oleh karena itu, diperlukan sebuah perencanaan agar rute pendistribusian yang ditempuh dapat optimal sehingga biaya distribusinya juga optimal.

Penelitian ini hanya membahas pendistribusian beras putri sejati $25 \mathrm{~kg}$ dari bulan Januari sampai Maret 2021. Dengan memperhitungkan biaya yang dikeluarkan perusahaan dari masing-masing agen ke tempat tujuan. Daerah pendistribusian yaitu Denpasar, Badung, dan Gianyar, dan diasumsikan jalur dapat dilalui oleh kendaraan perusahaan truk (pick-up).

\section{METODE PENELITIAN}

\section{Tempat dan Waktu Penelitian}

Tempat pelaksanaan penelitian ini adalah pada salah satu perusahaan pendistribusian beras di daerah Denpasar, yaitu pada UD Sinar Jaya Abadi. Sedangkan waktu yang digunakan penulis untuk mengumpulkan data dalam penelitian ini adalah dari bulan Januari sampai bulan Maret 2021.

\section{Jenis dan Sumber Data}

Data yang digunakan dalam penelitian ini diperoleh dari perusahaan UD Sinar Jaya Abadi. Data yang digunakan merupakan data sekunder. Data-data tersebut berupa data yang diperoleh dari dokumen atau pembukuan pada UD Sinar Jaya Abadi. Adapun data-data yang diperlukan yaitu data persediaan (supply), data permintaan (demand), banyaknya beras putri sejati $25 \mathrm{~kg}$ yang didistribusikan dari masingmasing agen ke tempat tujuan dan biaya transportasi dari sumber ke tempat tujuan.

\section{Variabel penelitian}

Variabel yang digunakan dalam penelitian ini adalah jumlah persediaan beras putri sejati $25 \mathrm{~kg}$ pada masing-masing agen $\left(a_{i j}\right) i=1,2,3$, jumlah permintaan beras putri sejati $25 \mathrm{~kg}$ pada masing-masing tujuan $\left(b_{i j}\right) j=1,2,3, \ldots, 8$, banyaknya beras putri sejati $25 \mathrm{~kg}$ yang didistribusikan dari agen $i$ ke tempat tujuan $j$ kemudian biaya yang dikeluarkan oleh UD Sinar Jaya Abadi dari agen $i$ ke tempat tujuan $j$ $\left(c_{i j}\right)$

Tabel 1. Nama Indeks $i$ dan $j$

\begin{tabular}{|c|l|c|l|}
\hline$i$ & Agen & $j$ & \multicolumn{1}{|c|}{ Tempat Tujuan } \\
\hline \multirow{2}{*}{1} & Monang & 1 & Toko Mekar Sari \\
\cline { 3 - 4 } & Maning & 2 & UD. Sinar Wangi \\
\hline \multirow{3}{*}{2} & \multirow{3}{*}{ Gatsu Barat } & 3 & Toko Sari Artha \\
\cline { 3 - 4 } & & 4 & UD. Mas Ayana \\
\cline { 3 - 4 } 3 & \multirow{3}{*}{3} & 5 & Toko Dharma \\
\cline { 3 - 4 } & \multirow{3}{*}{ Gianyar } & 6 & Toko Subur Jaya \\
\cline { 3 - 4 } & & 7 & UD Amertha \\
\cline { 3 - 4 } & & 8 & Toko Ayu Mega \\
\hline
\end{tabular}

\section{Metode Analisis Data}

Berikut merupakan langkah-langkah dalam analisis data yaitu :

1. Mengumpulkan data berupa data-data persediaan (supply), data permintaan (demand), biaya transportasi, dan banyaknya beras putri sejati $25 \mathrm{~kg}$ yang didistribusikan dari masing-masing agen ke tempat tujuan pada bulan Januari sampai Maret 2021 pada UD Sinar Jaya Abadi.

2. Membentuk fungsi tujuan dan fungsi kendala 
3. Menghitung solusi optimal dengan metode improved exponential approach dan zero suffix.

4. Interpretasi hasil

Langkah-langkah menghitung solusi optimal dengan improved exponential approach (Hidayat, 2016) :

1. Membentuk tabel transportasi dari persoalan transportasi yang telah diberikan

2. Membentuk tabel transportasi yang seimbang.

3. Mengurangi setiap entri baris $i(\operatorname{kolom} j)$ pada tabel transportasi dengan entri minimum baris $i$ (kolom $j$ ) masing-masing. Sehingga setiap baris $i$ (kolom $j$ ) pada tabel transportasi setidaknya memiliki satu nilai yang tereduksi menjadi nol.

4. a. Memilih biaya yang telah tereduksi menjadi nol pada entri kolom $j$. Kemudian memeriksa apakah jumlah permintaan pada kolom $j$ sudah kurang dari sama dengan jumlah persediaan pada baris yang bersesuaian dengan biaya yang tereduksi menjadi nol

b. Memilih biaya yang telah tereduksi menjadi nol pada entri baris $i$. Kemudian memeriksa apakah jumlah persediaan pada baris $i$ sudah kurang dari sama dengan jumlah permintaan pada kolom yang bersesuaian dengan biaya yang telah tereduksi menjadi nol.

Apabila langkah 4 telah terpenuhi lanjut ke langkah 6. Apabila belum maka lanjut ke langkah 5.

5. Membuat garis horizontal atau vertikal untuk setiap baris $i$ (kolom $j$ ) yang memiliki angka nol. Memilih biaya terkecil pada entri yang tidak terkena garis, selanjutnya biaya yang tidak terkena garis dikurangkan dengan biaya terkecil yang telah dipilih. Kemudian menambahkan biaya yang terpilih ke biaya yang terletak di perpotongan dua garis. Kembali ke langkah 4.

6. Memilih entri $i j$ yang telah tereduksi menjadi nol. Jika telah terpilih dilanjutkan dengan menetapkan penalti eksponen. Penalti eksponen adalah jumlah nol berturut-turut pada masing-masing baris $i$ dan $\operatorname{kolom} j$ yang bersesuaian dengan entri $i j$ yang terpilih. Jika entri $i j$ yang terpilih terletak pada entri 11 maka jumlahkan nilai nol yang terletak pada baris 1 dan kolom 1. Kemudian menghitung jumlah angka nol (tidak termasuk yang dipilih menjadi penalti eksponen) dalam baris dan kolom yang bersesuaian. Mengulangi prosedur untuk semua nol dalam tabel.

8. Menandai baris atau kolom yang telah dialokasikan untuk tidak dimasukkan dalam perhitungan selanjutnya. Kemudian kembali ke langkah 3 hingga semua permintaan dan persediaan terpenuhi.

9. Langkah terakhir yaitu menghitung biaya yang optimal.

Langkah-langkah menghitung solusi optimal dengan zero suffix (Fegade, 2012):

1. Membentuk tabel transportasi dari persoalan transportasi yang telah diberikan

2. Membentuk tabel transportasi yang seimbang.

3. Mengurangi setiap entri baris $i(\operatorname{kolom} j)$ pada tabel transportasi dengan entri minimum baris $i$ (kolom $j$ ) masing-masing. Sehingga setiap baris $i$ (kolom $j$ ) pada tabel transportasi setidaknya memiliki satu nilai yang tereduksi menjadi nol.

4. Memilih $i j$ yang telah tereduksi menjadi nol kemudian cari nilai suffix value. Suffix value (S) adalah penjumlahan biaya dari sisi yang berdekatan dengan entri $i j$ yang tereduksi menjadi nol yang lebih besar dari nol dibagi jumlah entri $i j$ yang ditambahkan. Apabila biaya terpilih terletak pada entri 11 maka nilai $\mathrm{S}$ adalah jumlah biaya pada entri 12 dan 21 dibagi 2, dengan prosedur yang sama cari Suffix Value untuk semua biaya yang telah tereduksi menjadi nol dalam tabel.

5. Pilih maksimum dari S, jika memiliki satu nilai maksimum maka terlebih dahulu diberikan pasokan untuk permintaan atau persediaan yang sesuai dengan entri $i j$ dengan nilai $\mathrm{S}$ yang paling maksimum. Apabila terdapat nilai yang bernilai sama maka pilih salah satu $\left\{a_{i j}, b_{i j}\right\}$ dan berikan permintaan atau persediaan semaksimal mungkin dengan memperhatikan persediaan atau permintaan.

6. Menandai baris atau kolom yang telah dialokasikan untuk tidak dimasukkan dalam perhitungan selanjutnya. Ulangi 3 hingga langkah 5 sampai semua permintaan terpenuhi.

7. Langkah terakhir yaitu menghitung biaya yang optimal. 


\section{HASIL DAN PEMBAHASAN}

\section{Data Penelitian}

UD Sinar Jaya Abadi adalah salah satu perusahaan pendistribusian yang berada di daerah Denpasar. Di tengah kondisi Covid-19 yang sedang terjadi perusahaan membatasi jenis beras yang didistribusikan, yaitu beras bermerek putri sejati $25 \mathrm{~kg}$. UD Sinar Jaya Abadi ini memiliki tiga agen yang masingmasing tersebar di daerah Denpasar, Badung, dan Gianyar. Proses pendistribusian beras yang dilakukan oleh UD. Sinar Jaya abadi ini dilakukan menggunakan kendaraan perusahaan berupa truk pick-up.

Tabel 2. Persediaan Masing-masing Agen

\begin{tabular}{|l|r|}
\hline \multicolumn{1}{|c|}{ Agen } & Persediaan (karung) \\
\hline Monang Maning & 4500 \\
\hline Gatsu Barat & 3250 \\
\hline Gianyar & 3750 \\
\hline \multicolumn{1}{|c|}{ Total } & 11500 \\
\hline
\end{tabular}

Tabel 3. Permintaan Masing-masing Tujuan

\begin{tabular}{|l|r|r|r|r|}
\hline \multirow{2}{*}{$\begin{array}{c}\text { Tempat } \\
\text { Tujuan }\end{array}$} & \multicolumn{3}{|c|}{$\begin{array}{c}\text { Permintaan } \\
\text { (karung) }\end{array}$} & $\begin{array}{c}\text { Jumlah } \\
\text { (karung) }\end{array}$ \\
\cline { 2 - 4 } & Jan & Feb & Mar & \\
\hline Mekar Sari & 250 & 150 & 200 & 600 \\
\hline Sinar Wangi & 550 & 450 & 250 & 1250 \\
\hline Sari Artha & 500 & 0 & 0 & 500 \\
\hline Mas Ayana & 670 & 530 & 0 & 1200 \\
\hline Dharma & 300 & 400 & 55 & 755 \\
\hline Subur Jaya & 400 & 0 & 580 & 980 \\
\hline Amertha & 0 & 615 & 500 & 1115 \\
\hline Ayu Mega & 0 & 850 & 0 & 850 \\
\hline \multicolumn{5}{|c|}{ Total } \\
\hline
\end{tabular}

Selanjutnya yaitu skema pendistribusian beras putri sejati $25 \mathrm{~kg}$ dari masing-masing agen ke tempat tujuan pada UD. Sinar Jaya Abadi. Adapun skema pendistribusian tersebut dapat dilihat pada Gambar 1.

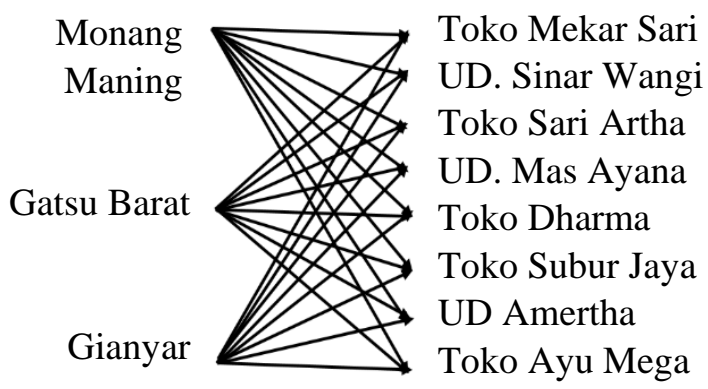

Gambar 1. Skema Pendistribusian Beras
Tabel 4. Distribusi Beras dari Agen ke Tujuan

\begin{tabular}{|c|c|c|c|c|}
\hline $\bar{i}$ & Agen & $j$ & Tempat Tujuan & Jmlh \\
\hline \multirow{8}{*}{1} & \multirow{8}{*}{$\begin{array}{l}\text { Monang } \\
\text { Maning }\end{array}$} & 1 & Toko Mekar Sari & 200 \\
\hline & & 2 & UD Sinar Wangi & 300 \\
\hline & & 3 & Toko Sari Artha & 150 \\
\hline & & 4 & UD Mas Ayana & 430 \\
\hline & & 5 & Toko Dharma & 155 \\
\hline & & 6 & Toko Subur Jaya & 500 \\
\hline & & 7 & UD Amertha & 315 \\
\hline & & 8 & Toko Ayu Mega & 150 \\
\hline \multirow{8}{*}{2} & \multirow{8}{*}{$\begin{array}{l}\text { Gatsu } \\
\text { Barat }\end{array}$} & 1 & Toko Mekar Sari & 250 \\
\hline & & 2 & UD Sinar Wangi & 400 \\
\hline & & 3 & Toko Sari Artha & 150 \\
\hline & & 4 & UD Mas Ayana & 400 \\
\hline & & 5 & Toko Dharma & 300 \\
\hline & & 6 & Toko Subur Jaya & 400 \\
\hline & & 7 & UD Amertha & 250 \\
\hline & & 8 & Toko Ayu Mega & 150 \\
\hline \multirow{8}{*}{3} & \multirow{8}{*}{ Gianyar } & 1 & Toko Mekar Sari & 150 \\
\hline & & 2 & UD Sinar Wangi & 550 \\
\hline & & 3 & Toko Sari Artha & 200 \\
\hline & & 4 & UD Mas Ayana & 370 \\
\hline & & 5 & Toko Dharma & 300 \\
\hline & & 6 & Toko Subur Jaya & 80 \\
\hline & & 7 & UD Amertha & 550 \\
\hline & & 8 & Toko Ayu Mega & 550 \\
\hline
\end{tabular}

Tabel 5. Biaya Rata-rata Distribusi

\begin{tabular}{|c|c|c|c|c|}
\hline$i$ & Agen & $j$ & Tempat Tujuan & biaya \\
\hline \multirow{8}{*}{1} & \multirow{8}{*}{$\begin{array}{l}\text { Monang } \\
\text { Maning }\end{array}$} & 1 & Toko Mekar Sari & 530 \\
\hline & & 2 & UD Sinar Wangi & 398 \\
\hline & & 3 & Toko Sari Artha & 300 \\
\hline & & 4 & UD Mas Ayana & 260 \\
\hline & & 5 & Toko Dharma & 635 \\
\hline & & 6 & Toko Subur Jaya & 200 \\
\hline & & 7 & UD Amertha & 150 \\
\hline & & 8 & Toko Ayu Mega & 333 \\
\hline \multirow{8}{*}{2} & \multirow{8}{*}{$\begin{array}{l}\text { Gatsu } \\
\text { Barat }\end{array}$} & 1 & Toko Mekar Sari & 800 \\
\hline & & 2 & UD Sinar Wangi & 214 \\
\hline & & 3 & Toko Sari Artha & 267 \\
\hline & & 4 & UD Mas Ayana & 225 \\
\hline & & 5 & Toko Dharma & 338 \\
\hline & & 6 & Toko Subur Jaya & 225 \\
\hline & & 7 & UD Amertha & 192 \\
\hline & & 8 & Toko Ayu Mega & 300 \\
\hline \multirow{8}{*}{3} & \multirow{8}{*}{ Gianyar } & 1 & Toko Mekar Sari & 600 \\
\hline & & 2 & UD Sinar Wangi & 176 \\
\hline & & 3 & Toko Sari Artha & 240 \\
\hline & & 4 & UD Mas Ayana & 322 \\
\hline & & 5 & Toko Dharma & 405 \\
\hline & & 6 & Toko Subur Jaya & 500 \\
\hline & & 7 & UD Amertha & 128 \\
\hline & & 8 & Toko Ayu Mega & 64 \\
\hline
\end{tabular}

Berdasarkan data pada Tabel 4 dan Tabel 5 diperoleh total biaya pendistribusian beras putri 
sejati $25 \mathrm{~kg}$ pada UD Sinar Jaya Abadi dari bulan Januari sampai Maret 2021 sebelum optimisasi adalah sebesar Rp 2.075.005,00

\section{Formulasi Model Permasalahan Pendistribusian Beras}

Berdasarkan Tabel 2 dan Tabel 3 dapat dilihat bahwa total persediaan dan permintaan beras putri sejati $25 \mathrm{~kg}$ berturut-urut dari bulan Januari sampai Maret 2021 adalah sebanyak 11500 dan 7250 karung. Sehingga dapat dikatakan bahwa persoalan transportasi ini belum seimbang karena terdapat kelebihan jumlah persediaan beras putri sejati $25 \mathrm{~kg}$ sebanyak 4250 karung. Untuk dapat menyerap kelebihan tersebut dapat ditambahkan kolom/ tujuan dummy dengan asumsi biaya distribusi sebesar 0. Sehingga formulasi model transportasi pada permasalahan pendistribusian beras putri sejati $25 \mathrm{~kg}$ yaitu sebagai berikut :

$$
\begin{aligned}
z= & 530 x_{11}+398 x_{12}+300 x_{13}+260 x_{14} \\
& +635 x_{15}+200 x_{16}+150 x_{17}+333 x_{18} \\
& +0 x_{19}+800 x_{21}+214 x_{22}+267 x_{23} \\
& +225 x_{24}+338 x_{25}+225 x_{26}+192 x_{27} \\
& +300 x_{28}+0 x_{29}+600 x_{31}+176 x_{32} \\
& +240 x_{33}+322 x_{34}+405 x_{35}+500 x_{36} \\
& +128 x_{37}+64 x_{38}+0 x_{39}
\end{aligned}
$$

dengan kendala

$$
\begin{aligned}
& x_{11}+x_{12}+x_{13}+x_{14}+x_{15}+x_{16}+x_{17}+ \\
& x_{18}+x_{19}=4500 \\
& x_{21}+x_{22}+x_{23}+x_{24}+x_{25}+x_{26}+x_{27}+ \\
& x_{28}+x_{29}=3250 \\
& x_{31}+x_{32}+x_{33}+x_{34}+x_{35}+x_{36}+x_{37}+ \\
& x_{38}+x_{39}=3750 \\
& x_{11}+x_{21}+x_{31}=600 \\
& x_{12}+x_{22}+x_{32}=1250 \\
& x_{13}+x_{23}+x_{33}=500 \\
& x_{14}+x_{24}+x_{34}=1200 \\
& x_{15}+x_{25}+x_{35}=755 \\
& x_{16}+x_{26}+x_{36}=980 \\
& x_{17}+x_{27}+x_{37}=1115
\end{aligned}
$$

$$
\begin{aligned}
& x_{18}+x_{28}+x_{38}=850 \\
& x_{19}+x_{29}+x_{39}=4250 \\
& x_{i j} \geq 0, i=1,2,3 \text { dan } j=1,2,3, \ldots, 9
\end{aligned}
$$

\section{Perhitungan Solusi Optimal}

Sebelum dilakukan perhitungan solusi optimal menggunakan metode improved exponential approach dan metode zero suffix, terlebih dahulu dibentuk tabel transportasi. Berdasarkan data yang telah diketahui yaitu beberapa agen dan tempat tujuan dapat dimisalkan MM adalah Agen Monang Maning, GB adalah Agen Gatsu Barat, GI adalah Agen Gianyar, MS adalah Toko Mekar Sari, SW adalah UD. Sinar Wangi, SA adalah Toko Sari Artha, MA adalah UD. Mas Ayana, D adalah Toko Dharma, SJ adalah Toko Subur Jaya, A adalah UD. Amertha, AM adalah Toko Ayu Mega, $d$ adalah Variabel Dummy, Su adalah

\begin{tabular}{|c|c|c|c|c|c|c|c|c|c|c|}
\hline \multirow{2}{*}{ Agen } & \multicolumn{9}{|c|}{ Tujuan } & \multirow{2}{*}{$\mathrm{Su}$} \\
\hline & MS & SW & SA & MA & $\mathrm{D}$ & SJ & $\mathrm{A}$ & $\mathrm{AM}$ & $\mathrm{d}$ & \\
\hline \multirow{2}{*}{ MM } & 530 & 398 & 300 & 260 & 635 & 200 & 150 & 333 & 0 & \multirow{2}{*}{4500} \\
\hline & & & & & & & & & & \\
\hline GB & 800 & 214 & 267 & 225 & 338 & 225 & 192 & 300 & 0 & 3250 \\
\hline$r$ & 600 & 176 & 240 & 322 & 405 & 500 & 128 & 64 & 0 & \\
\hline $\mathrm{De}$ & 600 & 1250 & 500 & 1200 & 755 & 980 & 1115 & 850 & 4250 & 11500 \\
\hline
\end{tabular}
Persediaan (Supply), De adalah Permintaan (Demand).

\section{Perhitungan Solusi Optimal Improved Exponential Approach Method}

1. Untuk dapat menyelesaikan persoalan transportasi ini dapat dibuat sebuah matriks $m \times n$ dengan entri $i j$ merupakan biaya dari masing-masing agen $(i)$ ke masing-masing tujuan $(j)$. Berdasarkan formulasi model yang telah dibuat diketahui bahwa pada kasus ini terdapat 3 agen dan 9 tujuan sehingga dapat dibuat matriks $3 \times 9$. Berdasarkan Tabel 4 entri $i j$ merupakan biaya distribusi rata-rata perkarung beras dari masing-masing agen $(i)$ ke masing-masing tujuan $(j)$. Dapat disajikan dalam tabel yang tersusun seperti pada Tabel 6.

2. Pada Tabel 6 dapat diketahui bahwa pada persoalan transportasi ini terdapat penambahan kolom dummy. Sehingga lanjut ke langkah 3.

Tabel 6. Tabel Transportasi Awal 
3. Kurangi setiap entri baris $i$ dengan entri minimum baris masing-masing. Kemudian kurangi setiap entri kolom $j$ dengan entri minimum kolom masing-masing. Dapat dilihat pada Tabel 7.

Tabel 7. Pengurangan Entri Kolom dan Baris Minimum

\begin{tabular}{|c|c|c|c|c|c|c|c|c|c|c|}
\hline \multirow{2}{*}{ Agen } & \multicolumn{9}{|c|}{ Tujuan } & \multirow{2}{*}{$\mathrm{Su}$} \\
\hline & MS & SW & SA & MA & $\mathrm{D}$ & $\mathrm{SJ}$ & A & $\mathrm{AM}$ & $\mathrm{d}$ & \\
\hline MM & 0 & 222 & 60 & 35 & 297 & 0 & 21 & 269 & 0 & 4500 \\
\hline GB & 270 & 37 & 27 & 0 & 0 & 25 & 63 & 236 & 0 & 3250 \\
\hline GI & 70 & 0 & 0 & 97 & 67 & 300 & 0 & 0 & 0 & 3750 \\
\hline $\mathrm{De}$ & 600 & 1250 & 500 & 1200 & 755 & 980 & 1115 & 850 & 4250 & 11500 \\
\hline
\end{tabular}

4. Kemudian berdasarkan Tabel 7.

a. Memilih biaya yang telah tereduksi menjadi nol pada entri kolom $j$. Kemudian memeriksa apakah jumlah permintaan pada kolom $j$ sudah kurang dari sama dengan jumlah persediaan pada baris yang bersesuaian dengan biaya yang tereduksi menjadi nol.

$$
\begin{array}{lll}
600<4500 & 1250<3750 & 500<3750 \\
1200<3250 & 775<3250 & 980<4500 \\
1115<3750 & 850<3750 &
\end{array}
$$

b. Memilih biaya yang telah tereduksi menjadi nol pada entri baris $i$. Kemudian memeriksa apakah jumlah persediaan pada baris $i$ sudah kurang dari sama dengan jumlah permintaan pada kolom yang bersesuaian dengan biaya yang telah tereduksi menjadi nol.

$4500<600+980+4250$

$3250<1200+755+4250$

$3750<1250+500+1115+850+4250$

Karena langkah $4 \mathrm{a}$ dan $4 \mathrm{~b}$ telah terpenuhi yaitu jumlah permintaan (persediaan) pada masingmasing kolom (baris) sudah kurang dari sama dengan jumlah persediaan (permintaan) pada baris (kolom) yang bersesuaian dengan biaya yang telah tereduksi menjadi nol. Lanjut ke langkah 6 .

Langkah 6 menentukan penalti eksponennya Kemudian menghitung jumlah angka nol (tidak termasuk yang dipilih)

1. baris 1 dan kolom 1 penalti eksponennya 2 jumlah nol (tidak termasuk yang dipilih) 8 .

2. baris 1 dan kolom 6 penalti eksponennya 2 jumlah nol (tidak termasuk yang dipilih) 8 .

3. baris 2 dan kolom 4 penalti eksponennya 2 jumlah nol (tidak termasuk yang dipilih) 8 .
4. baris 2 dan kolom 5 penalti eksponennya 2 jumlah nol (tidak termasuk yang dipilih) 8 .

5. baris 3 dan kolom 2 penalti eksponennya 4 jumlah nol (tidak termasuk yang dipilih) 6 .

6. baris 3 dan kolom 3 penalti eksponennya 4 jumlah nol (tidak termasuk yang dipilih) 6 .

7. baris 3 dan kolom 3 penalti eksponennya 4 jumlah nol (tidak termasuk yang dipilih) 6 .

8. baris 3 dan kolom 8 penalti eksponennya 4 jumlah nol (tidak termasuk yang dipilih) 6 .

Didapatkan nilai penalti eksponen minimum terletak pada entri $c_{11}, c_{16}, c_{24}, c_{25}$. Karena terdapat lebih dari satu entri $c_{i j}$ dengan nilai penalti eksponen minimum, maka dipilih entri $c_{i j}$ dengan biaya terendah pada tabel awal transportasi. Berdasarkan Tabel 6 biaya terendah terletak pada entri $c_{16}$. Sehingga alokasikan sebanyak 980 karung beras putri sejati $25 \mathrm{~kg}$ dari agen MM ke tujuan SJ $\left(x_{16}\right)$. Berdasarkan pengalokasian tersebut tujuan SJ telah terpenuhi permintaannya Sehingga pada tabel berikutnya tujuan SJ sudah tidak masuk perhitungan. Untuk dapat memenuhi seluruh permintaan dapat diulangi langkah 3 sampai 6 hingga seluruh permintaan dan persediaan terpenuhi. Dapat dilihat pada Tabel 8 untuk hasil akhir pengalokasian menggunakan metode improved exponential approach.

\section{Perhitungan Solusi Optimal Zero Suffix}

Langkah 1 Membentuk tabel transportasi dari persoalan transportasi yang telah diberikan (Tabel 6. Tabel Transportasi Awal). Karena tabel transportasi telah seimbang maka sesuai langkah-langkah pada metode zero suffix lanjut ke langkah 3. Kurangi setiap entri kolom $j$ dari 
minimum kolom masing-masing kemudian kurangi setiap entri baris $i$ dari minimum baris masing-masing (Tabel 7. Pengurangan Entri Kolom dan Baris Minimum).

Langkah 4 dapat dilihat pada Tabel 7 cari nilai suffix value $(S)$ dari semua biaya yang telah tereduksi menjadi nol.

Perhitungannya sebagai berikut :

$c_{11}=\frac{270+222}{2}=\frac{492}{2}=246$

$c_{16}=\frac{297+25+21}{3}=\frac{343}{3}=114$

$c_{24}=\frac{35+27+98}{3}=\frac{160}{4}=53$

$c_{25}=\frac{297+67+25}{3}=\frac{389}{3}=133$

$c_{32}=\frac{70+38}{2}=\frac{108}{2}=54$

$c_{33}=\frac{27+97}{2}=\frac{124}{2}=62$ $c_{37}=\frac{300+63}{2}=\frac{363}{3}=182$

$c_{38}=\frac{236}{1}=236$

Langkah 5 pilih nilai S yang paling maksimum. Karena terdapat satu nilai $\mathrm{S}$ maksimum yang terletak pada entri $c_{11}$ maka sesuai dengan permintaan dan persediaan dapat dialokasikan sebanyak 600 karung beras putri sejati $25 \mathrm{~kg}$ dari agen MM ke tujuan MS $\left(x_{11}\right)$.Berdasarkan pengalokasian tersebut tujuan MS telah terpenuhi permintaannya Sehingga pada tabel berikutnya tujuan MS sudah tidak masuk perhitungan. Untuk dapat memenuhi seluruh permintaan dapat diulangi langkah 3 sampai 5 hingga seluruh permintaan dan persediaan terpenuhi. Dapat dilihat pada Tabel 8 untuk hasil akhir pengalokasian menggunakan metode zero suffix.

Tabel 8. Hasil Akhir Perhitungan Metode IEA dan Zero Suffix

\begin{tabular}{|c|c|c|c|c|c|c|c|c|c|c|}
\hline \multirow{2}{*}{ Agen } & \multicolumn{9}{|c|}{ Tujuan } & \multirow{2}{*}{$\mathrm{Su}$} \\
\hline & MS & SW & SA & MA & $\mathrm{D}$ & SJ & A & $\mathrm{AM}$ & $\mathrm{d}$ & \\
\hline \multirow{2}{*}{$\mathrm{MM}$} & 530 & 398 & 300 & 260 & 635 & 200 & 150 & 333 & 0 & \multirow{2}{*}{4500} \\
\hline & 600 & & & & & 980 & & & 2920 & \\
\hline \multirow{2}{*}{ GB } & 800 & 214 & 267 & 225 & 338 & 225 & 192 & 300 & 0 & \multirow{2}{*}{3250} \\
\hline & & & & 1200 & 755 & & & & 1295 & \\
\hline \multirow{2}{*}{ GI } & 600 & 176 & 240 & 322 & 405 & 500 & 128 & 64 & 0 & \multirow{2}{*}{3750} \\
\hline & & 1250 & 500 & & & & 1115 & 850 & 35 & \\
\hline $\mathrm{De}$ & 600 & 1250 & 500 & 1200 & 755 & 980 & 1115 & 850 & 4250 & 11500 \\
\hline
\end{tabular}

Dapat dilihat pada Tabel 8 bahwa untuk seluruh baris persediaan dan kolom permintaan telah optimal menggunakan metode improved exponential approach dan metode zero suffix. Dengan demikian diperoleh biaya distribusi optimal beras putri sejati $25 \mathrm{~kg}$ dari bulan Januari sampai Maret 2021 sesuai dengan Tabel 8 sebagai berikut :

$$
\begin{aligned}
z= & 530 x_{11}+200 x_{16}+0 x_{19}+225 x_{24} \\
& +338 x_{25}+0 x_{29}+176 x_{32}+240 x_{33} \\
& +128 x_{37}+64 x_{38}+0 x_{39} \\
z= & 530(600)+200(980)+0(2920) \\
& +225(1200)+338(755)+0(1295) \\
& +176(1250)+240(500)+128(1115) \\
& +64(850)+0(35)
\end{aligned}
$$$$
z=\operatorname{Rp} 1.575 .815,00
$$

\section{Interpretasi Hasil}

Berdasarkan perhitungan yang telah dilakukan diperoleh perbandingan total biaya yang dikeluarkan menggunakan metode improved exponential approach dan metode zero suffix. Adapun perbandingan biaya pendistribusian setelah dilakukan optimisasi dapat dilihat pada Tabel 9 .

Tabel 9. Perbandingan Total Biaya Distribusi

\begin{tabular}{|l|c|l|}
\hline Metode & $\begin{array}{l}\text { Jumlah } \\
\text { Iterasi }\end{array}$ & $\begin{array}{l}\text { Biaya } \\
\text { Pendistribusian }\end{array}$ \\
\hline Metode IEA & 8 & Rp 1.575.815,00 \\
\hline $\begin{array}{l}\text { Metode zero } \\
\text { suffix }\end{array}$ & 8 & Rp 1.575.815,00 \\
\hline
\end{tabular}

Berdasarkan hasil perhitungan yang telah dilakukan, kedua metode tersebut menghasilkan tiga rute pendistribusian yang sama. Jalur pendistribusian pertama yaitu dari 
agen Monang Maning ke toko Mekar Sari dan toko Subur Jaya. Jalur pendistribusian kedua dari agen Gatsu Barat ke UD Mas Ayana dan toko Dharma. Jalur ketiga dari agen Gianyar ke UD Sinar Wangi, toko Sari Artha, UD Amertha, dan toko Ayu Mega dengan biaya pendistribusian optimal yaitu sebesar $\mathrm{Rp}$ 1.575.815,00. Adapun selisih atau efisiensi total biaya yang dikeluarkan dalam pendistribusian sebelum dan sesudah optimisasi oleh UD Sinar Jaya Abadi sebesar Rp 499.190.00 atau 24\%.

\section{KESIMPULAN DAN SARAN}

Penerapan model transportasi dengan metode langsung yaitu metode Improved Exponential Approach dan metode Zero Suffix diperoleh tiga jalur atau rute pendistribusian yang sama. Jalur pendistribusian pertama yaitu dari agen Monang Maning ke toko Mekar Sari dan toko Subur Jaya. Jalur pendistribusian kedua dari agen Gatsu Barat ke UD Mas Ayana dan toko Dharma. Jalur ketiga dari agen Gianyar ke UD Sinar Wangi, toko Sari Artha, UD Amertha, dan toko Ayu Mega dengan biaya pendistribusian optimal yaitu sebesar $\mathrm{Rp}$ 1.575.815,00. Adapun selisih atau efisiensi total biaya yang dikeluarkan dalam pendistribusian sebelum dan sesudah optimisasi oleh UD Sinar Jaya Abadi sebesar Rp 499.190.00 atau 24\%.

Adapun saran untuk penelitian selanjutnya terkait pengoptimalan biaya distribusi menggunakan metode transportasi yaitu peneliti dapat membandingkan hasil optimal menggunakan metode improved exponential approach dan metode zero suffix dengan melibatkan faktor kemacetan pada jalur yang akan ditempuh dan juga dapat membandingkan hasil optimal menggunakan metode improved exponential approach atau metode zero suffix dengan metode transportasi lainnya, misalkan seperti metode zero neigbouring atau metode TOCM SUM

\section{DAFTAR PUSTAKA}

Badan Pusat Statistik 2017. Analisis Usaha Tani Tanaman Padi Jagung dan Kedelai Tahun 2017. Katalog BPS

Fegade, M. R. 2012. Solving Fuzzy Transportation Problem Using Zero Suffix And Robust Ranking Methodology. IOSR Journal Of Engineering, 02(07), 36-39
Hasan, M. K. 2012. Direct Methods For Finding Optimal Solution Of a Transportation Problem Are Not Always Reliable. International Refereed Journal of Engineering And Science (IRJES) ISSN (Online), 1(2), 2319-183.

Hidayat, D. A. 2016.. Metode Improved Exponential Approach dalam Menentukan Solusi Optimum pada Masalah Transportasi. Jurnal Matematika (Universitas Diponegoro), 5(3).251-259

Karundeng, T. N., Mandey, S. L., \& Sumarauw, J. S. B. 2018. Analisis Saluran Distribusi Kayu (Studi Kasus Di CV Karya Abadi, Manado). Jurnal EMBA: Jurnal Riset Ekonomi, Manajemen, Bisnis Dan Akuntansi, 6(3), 1748-1757

Kertiasih, N. K. 2012. Penggunaan Metode Transportasi Dalam Program Linier Untuk Pendistribusian Barang. Jurnal Pendidikan Teknologi Dan Kejuruan, 6(2), 27-35.

Purwanti, L. E., Kiftiah, M., \& Fran, F. 2019. Penerapan Metode Zero Suffix dalam Menyelesaikan Masalah Transportasi Fuzzy Dan Linier Studi Kasus : Perum Bulog Divre Kalbar Pontianak. Jurnal Matematika 08(2), 229-238.

Septiana, A. R., Solikhin, \& Ratnasari, L. 2017. Metode ASM pada Masalah Transportasi Seimbang. Jurnal Matematika, 20(2), 7178. 